\title{
Efesiensi Tataniaga Cabai Rawit di Kabupaten Kotawaringin Barat
}

\section{(Cayenne Pepper Marketing Efficiency in Kotawaringin Barat Regency)}

\author{
Novi Nurhayati \\ Program Studi Agribisnis, Fakultas Pertanian \\ Universitas Antakusuma Pangkalan Bun \\ noviuntama@gmail.com
}

\begin{abstract}
ABSTRAK
Pemasaran cabai rawit merupakan pemasaran yang unik, dimana harga cabai selalu mengalami fluktuasi. Di dalam pemasaran cabai rawit melibatkan lembaga-lembaga pemasaran yang sangat mempunyai peranan penting dalam menyalurkan cabai rawit dari produsen sampai dengan konsumen. Tujuan penelitian ini adalah untuk mengetahui saluran, lembaga, fungsi lembaga pemasaran serta efeseinsi dari tataniaga pemasaran cabai rawit di Kabupaten Kotawaringin Barat. Penelitian dilaksanakan di Pangkalan Bun, dari bulan Juli - September 2019. Metode penelitian yang dipergunakan adalah metode deskriptif untuk mengetahui saluran, dan fungsi lembaga pemasaran, sedangkan untuk mengetahui efesiensi tataniaga cabai rawit menggunakan analisis margin pemasaran dan farmers share. Hasil penelitian ini adalah saluran tataniaga cabai rawit di Kabupaten Kotawaringin Barat ada tiga tingkatan saluran pemasaran, yaitu saluran dua tingkat, saluran tiga tingkat dan saluran empat tingkat. Lembaga pemasaran yang terlibat dalam tataniaga cabai rawit meliputi pedagang pengumpul, pedagang grosir, dan pedagang eceran. Pedagang pengumpul mempunyai fungsi mengumpulkan cabai rawit dari petani dan menjualnya kembali, pedagang grosir mempunyai fungsi membeli cabai rawit dari pedagang pengumpul dan menjualnya kembali, sedangkan pedagang eceran mempunyai fungsi membeli cabai rawit dari pedagang pengumpul maupun grosir dan menjual langsung kepada konsumen. Efesiensi tataniaga pemasaran cabai rawit di Kabupaten Kotawaringin Barat terdapat pada saluran pemasaran 2 (dua) tingkat, dengan margin pemasaran bernilai Rp. 40.000.- serta farmers share sebesar 72,41\%.
\end{abstract}

Kata Kunci : Efesiensi, tataniaga, cabai rawit, saluran.

\begin{abstract}
Marketing Chili pepper is unique marketing, where the price of chili is always fluctuating. In marketing, chili pepper involves marketing institutions that have a significant role in channeling chili pepper from producers to consumers. The purpose of this research is to know the channel, institution, a function of the marketing institution as well as the affection of the marketing Tataniaga of chili pepper in Kotawaringin Barat Regency. The study was conducted at Pangkalan Bun, from July - September 2019. The method of research used is a descriptive method to know the channel, and the function of the marketing institution, while to know the efficiency of chili pepper, the use of marketing margin analysis and farmer's share. The result of this research is a channel of cayenne Pepper in Kotawaringin Barat district there are three levels of marketing channels, namely two-level channels, three-level channels, and four-level channels. The marketing institutions involved in cayenne pepper include collector merchants, wholesalers, and retailers. Collector traders have the function of collecting chili pepper from the farmer and resell it, wholesalers have the function of buying chili pepper from the collecting merchant and resell it, while the retail trader has the function of buying chili From collecting merchants and wholesalers and selling directly to consumers. The marketing efficiency of chili pepper in Kotawaringin Barat District is on the Marketing Channel 2 (two) levels, with a marketing margin worth Rp. 40,000.- and farmers share by $72.41 \%$.
\end{abstract}

Keywords: Efficiency, marketing, cayenne pepper, channel.

\section{PENDAHULUAN}

Tanaman cabai merupakan tanaman hortikultura, yang selalu diminati oleh masyarakat sebagai bahan penambah rasa dalam makanan. Pemasaran buah cabai ini merupakan saluran pemasaran yang unik, dimana permintaan dan harga buah cabai selalu berfluktuasi mengikuti musim ataupun hari-hari besar seperti musim hujan, musim 
kemarau, hari raya idul fitri dan pada bulan desember.

Pemasaran komoditi pertanian merupakan hal yang unik untuk diteliti. Pemasaran hasil pertanian yang efesien merupakan pemasaran yang sangat didambakan baik dari pihak produsen dalam hal ini petani, penjual ataupun pihak konsumen. Dalam pemasaran hasil pertanian banyak melibatkan lembaga-lembaga seperti produsen, tengkulak, pengecer sampai dengan konsumen.

Kabupaten Kotawaringin Barat merupakan salah satu kabupaten yang ada di Provinsi Kalimantan Tengah. Kabupaten Kotawaringin Barat mempunyai iklim tropis yang cocok untuk berbudidaya tanaman cabai. Berikut ini adalah produksi cabai di Kabupaten Kotawaringin Barat.

Tabel 1. Produksi Cabai Di Kabupaten Kotawaringin Barat Dalam 2 (Dua) Tahun Terakhir

\begin{tabular}{lll}
\hline \multirow{2}{*}{ Kecamatan } & \multicolumn{2}{c}{ Produksi Cabai Rawit (Ton) } \\
\cline { 2 - 3 } & Tahun 2017 & Tahun 2018 \\
\hline Kotawaringin Lama & 9,90 & 9 \\
Arut Selatan & 129,00 & 159 \\
Kumai & 29,00 & 36 \\
Pangkalan Banteng & 68,50 & 3.645 \\
Pangkalan Lada & 12,20 & 53 \\
Arut Utara & 4,20 & 4 \\
\hline Jumlah & 252,80 & 3.906 \\
\hline
\end{tabular}

Sumber : Kotawaringin Barat Dalam Angka Tahun 2018 dan Tahun 2019.

Berdasarkan Tabel 1 diatas produksi cabai rawit meningkat dari Tahun 2017 sebesar 252,80 ton menjadi 3.906 ton pada Tahun 2018. Kenaikan ini sangat signifikan sekali, dan pada umumnya akan mempengaruhi pemasaran buah cabai itu sendiri. Dari latar belakang tersebut, peneliti ingin mengetahui tingkat efesiensi pemasaran cabai rawit. Lokasi penelitian ini dilakukan di Kabupaten Kotawaringin Barat. Tujuan dari penelitian ini adalah (i) mengidentifikasi saluran, lembaga, fungsi, (ii) menganalisis struktur dan perilaku pasar tataniaga cabai rawit di Kabupaten Kotawaringin Barat, (iii) menganalisis efisiensi tataniaga cabai rawit pada setiap saluran tataniaga di Kabupaten Kotawaringin Barat dengan pendekatan marjin tataniaga, farmer's share.

\section{METODOLOGI PENELITIAN}

Penelitian ini dilaksanakan di Pangkalan Bun, Kabupaten Kotawaringin Barat dari bulan Juli - September 2019. Bahan yang digunakan dalam penelitian ini adalah data primer dan data sekunder. Data primer diperoleh langsung dari hasil penelitian sedangkan data sekunder diperoleh dari Badan Pusat Statistik Kotawaringin Barat. Alat yang menunjang dalam penelitian ini adalah alat tulis dan komputer untuk mengolah data. Sampel yang digunakan dalam penelitian ini sebanyak 100 petani cabai rawit.

Metode analisis yang digunakan adalah : Identifikasi saluran, lembaga, fungsi, serta menganalisis struktur dan perilaku pasar tataniaga cabai rawit di Kabupaten Kotawaringin Barat, dengan menggunakan metode deskriptif. Efeseinsi Pemasaran dengan pendekatan marjin tataniaga, farmer's share. Menurut Sudiyono (2004), menyatakan bahwa marjin tataniaga menggambarkan perbedaan harga di tingkat konsumen (Pr) dengan harga ditingkat produsen $(\mathrm{Pf})$, secara matematika dapat dituliskan sebagai berikut :

$\mathrm{Mr}=\mathrm{Pr}-\mathrm{Pf}$

$\mathrm{Mr}=$ Margin Pemasaran $(\mathrm{Rp})$

$\operatorname{Pr}=$ Harga ditingkat konsumen $(\mathrm{Rp})$

$\mathrm{Pf}=$ Harga ditingkat produsen $(\mathrm{Rp})$

Menurut Kohls dan Uhls (2002), farmer's share dapat dipengaruhi oleh tingkat pengolahan, keawetan produk, ukuran produk, 
jumlah produk, dan biaya transportasi. Nilai farmer's share ditentukan oleh besarnya rasio harga yang diterima produsen $\left(\mathrm{P}_{\mathrm{f}}\right)$ dan harga yang dibayarkan oleh konsumen $\left(\mathrm{P}_{\mathrm{r}}\right)$. Secara matematika dapat dirumuskan dengan persamaan sebagai berikut:

$$
\mathrm{Fs}=\frac{P f}{P r} x 100 \%
$$

\section{HASIL DAN PEMBAHASAN}

\section{Keadaan Umum Wilayah Penelitian}

Kabupaten Kotawaringin Barat merupakan salah satu kabupaten yang ada di Provinsi Kalimantan Tengah. Ibukota Kabupaten Kotawaringin Barat berada di
Kota Pangkalan Bun, terletak di daerah khatulistiwa diantara $1^{0} 19^{\prime}-3^{0} 36^{\prime}$ LS, $110^{0} 25^{\prime}-112^{0} 50^{\prime}$ BT dengan luas wilayah $10.759 \mathrm{~km}^{2}$. Iklim di Kabupaten Kotawaringin Barat secara umum beriklim tropis yang dipengaruhi oleh musim kemarau dan musim hujan (BPS, 2018). Pada Tahun 2018, jumlah penduduk di Kabupaten Kotawaringin Barat berjumlah 304.082 jiwa yang terdiri dari 142.868 laki-laki dan 161.214 wanita (BPS, 2019).

Responden petani yang digunakan dalam penelitian ini adalah petani yang membudidayakan cabai rawit, dengan jumlah responden 100 petani. Berikut ini adalah karakteristik responden petani cabai rawit di Kabupaten Kotawaringin Barat yang meliputi tingkat pendidikan dan umur petani

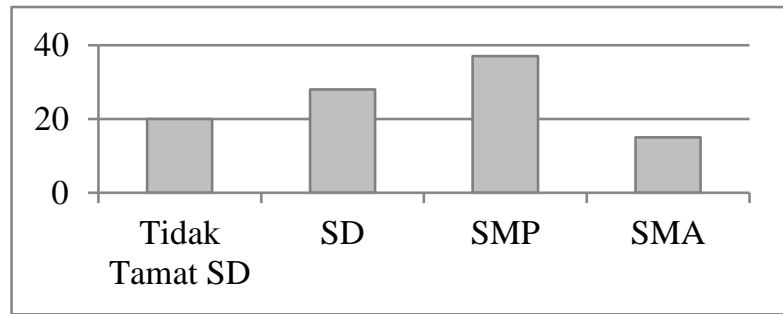

Gambar 1. Diagram Tingkat Pendidikan Petani Cabai Rawit

Berdasarkan gambar 1 diatas, tingkat pendidikan petani cabai rawit yang menjadi responden tidak tamat $\mathrm{SD}$ berjumlah 20 petani, pendidikan SD 28 petani, pendidikan SMP 37 petani dan pendidikan SMA 15 petani

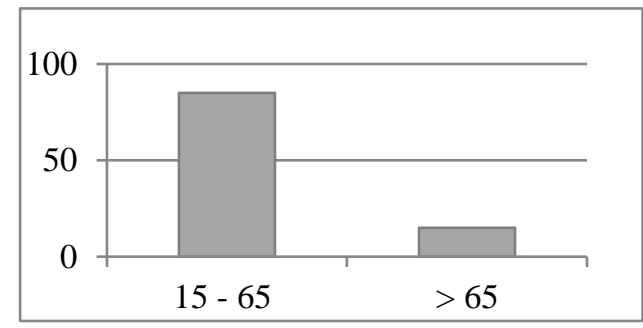

Gambar 2. Diagram Umur Petani Cabai rawit

Berdasarkan Gambar 2 diatas, umur petani cabai rawit antara 15 - 65 tahun berjumlah 85 petani dan yang berumur diatas 65 tahun berjumlah 15 petani.

Jumlah pedagang yang menjadi responden dalam penelitian ini berjumlah 50 pedagang, yang terdiri dari pedagang pengumpul berjumlah 5 pedagang, pedagang grosir berjumla 10 pedagang, pedagang pengecer I berjumlah15 pedagang dan pedagang pengecer II berjumlah 20 pedagang.

\section{Saluran Tataniaga Cabai Rawit}

Saluran tataniaga merupakan rute yang dilalui oleh produk pertanian ketika produk bergerak dari petani produsen ke pemakai terakhir (konsumen). Pada umunya saluran pemasaran terdiri atas sejumlah lembaga pemasaran dan pelaku pendukung. Hal ini sesuai dengan pendapat Limbong dan 
Sitorus (1987), yang menyatakan saluran tataniaga merupakan himpunan perusahaan atau perorangan yang mengambil alih hak atau membantu dalam pengalihan hak atas barang atau jasa tertentu selama barang atau jasa tersebut bepindah dari produsen kekonsumen.

Saluran tataniaga menunjukkan banyaknya lembaga tataniaga yang saling tergantung dan terlibat dalam proses untuk menjadikan produk atau jasa siap untuk digunakan atau dikonsumsi oleh konsumen

Berdasarkan hasil penelitian saluran tataniaga cabai rawit di Kabupaten Kotawaringin Barat memiliki 3 (tiga ) saluran tataniaga pemasaran. Berikut ini adalah gambar saluran tataniaga cabai rawit di Kabupaten Kotawaringin Barat.

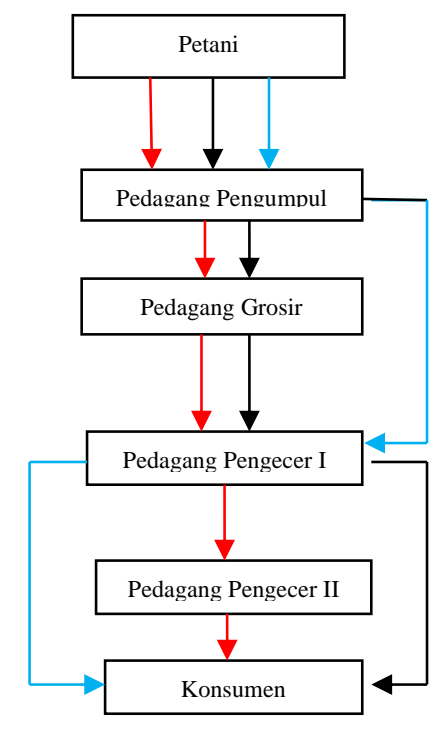

Keterangan. $\longrightarrow$ (Pola Saluran I), $\longrightarrow$ (Pola saluran II), $\longrightarrow$ (Pola Saluran III)

Gambar 1. Saluran Pemasaran Cabai Rawit di Kabupaten Kotawaringin Barat, 2019.

Berdasarkan Gambar 1 diatas, terlihat ada 3 (tiga ) pola saluran pemasaran. Pola saluran yang pertama dimulai dari petani sebagai produsen kemudian dijual kepada pedagang pengumpul yang dilanjutkan kepedagang grosir kepedagang pengecer I dan yang terakhir adalah kekonsumen. Pola saluran I disebut dengan saluran pemasaran tingkat tiga, karena ada tiga lembaga pemasaran yang berperan dalam penyaluran cabai rawit dari produsen sampai konsumen. Pola saluran yang kedua dimulai dari petani sebagai produsen dilanjutkan kepedagang pengumpul kemudian kepedagang pengecer I dan yang terakhir adalah kekonsumen. Pola saluran II disebut dengan saluran pemasaran tingkat dua, karena ada dua lembaga pemasaran yang berperan dalam penyaluran cabai rawit dari produsen sampai konsumen. Pola saluran yang ketiga dimulai dari petani sebagai produsen kemudian menjual ke pedagang pengumpul dilanjutkan kepedagang grosir selanjutnya kepedagang pengecer I ke pedagang pengecer II dan yang terakhir ke konsumen. Pola saluran III disebut dengan saluran pemasaran tingkat empat, karena ada empat lembaga pemasaran yang berperan dalam penyaluran cabai rawit dari produsen sampai konsumen.

Pola saluran tataniaga cabai rawit di Kabupaten Kotawaringin Barat ada beberapa tingkatan. Pada pola saluran I merupakan saluran tataniaga tingkat III, karena ada 3 (tiga ) lembaga yang dilewati cabai rawit untuk sampai ke konsumen, yaitu lembaga pedagang pengumpul, pedagang grosir dan pedagang pengecer. Pada pola saluran II merupakan saluran tataniaga tingkat II, karena ada 2 (dua) lembaga yang dilewati cabai rawit untuk sampai ke konsumen, yaitu lembaga pedagang pengumpul, dan pedagang pengecer. Pada pola saluran III merupakan 
saluran tataniaga tingkat IV, karena ada 4 (empat) lembaga yang dilewati cabai rawit untuk sampai ke konsumen, yaitu lembaga pedagang pengumpul, pedagang grosir, pedagang pengecer I dan pedagang pengecer II. Hal ini sesuai dengan pendapat Kotler (2002), yang menggambarkan panjangnya saluran pemasaran dengan membagi saluran pemasaran dalam beberapa tingkatan, seperti saluran nol tingkat, saluran satu tingkat, saluran dua tingkat, saluran tiga tingkat dan seterusnya berdasarkan jumlah lembaga yang dilewati suatu produk untuk sampai kekonsumen.

Lembaga-lembaga pemasaran yang terlibat dalam tataniaga cabai rawit di Kabupaten Kotawaringin Barat adalah pedagang pengumpul, pedagang grosir dan pedagang pengecer. Lembaga pedagang pengumpul, pedagang grosir dan pedagang pengecer adalah lembaga pemasran yang memiliki barang untuk dapat dijual kembali dengan mengambil keuntungan dari barang yang dijual. Lembaga-lembaga ini mempunyai peranan dalam menyampaikan barang dari produsen sampai dengan kekonsumen, hal ini sesuai dengan pendapat Limbong dan Sitorus (1987), yang menyatakan lembaga tataniaga merupakan badan-badan yang berusaha dalam tataniaga menggerakkan barang dari produsen kekonsumen melalui penjualan. Diperkuat lagi dengan pendapat Sudiyono (2004), lembaga pemasaran adalah badan usaha atau individu yang menyelenggarakan pemasaran, menyalurkan jasa dan komoditas dari produsen sampai konsumen akhir.

\section{Fungsi Tataniaga Cabai Rawit}

Fungsi tataniaga merupakan fungsifungsi yang dilakukan dalam tataniaga cabai rawit dari petani sampai kekonsumen, fungsifungsi ini meliputi fungsi pertukaran, fungsi fisik dan fungsi fasilitas. Fungsi-fungsi tataniaga cabai rawit di Kabupaten Kotawaringin Barat adalah sebagai berikut :

Tabel 2. Fungsi-Fungsi Tataniaga Cabai rawit di Kabupaten Kotawaringin Barat

\begin{tabular}{|c|c|c|c|c|c|c|c|c|}
\hline \multirow{3}{*}{$\begin{array}{c}\text { Saluran dan Lembaga } \\
\text { Tataniaga }\end{array}$} & \multicolumn{8}{|c|}{ Fungsi-Fungsi Tataniaga } \\
\hline & \multicolumn{2}{|c|}{ Pertukaran } & \multicolumn{2}{|c|}{ Fisik } & \multicolumn{4}{|c|}{ Fasilitas } \\
\hline & Jual & Beli & Simpan & Angkut & Sortasi & Resiko & Biaya & Informasi Pasar \\
\hline \multicolumn{9}{|l|}{ Saluran I } \\
\hline Petani & $\sqrt{ }$ & - & - & $*$ & - & - & - & $\sqrt{ }$ \\
\hline Pedagang Pengumpul & $\sqrt{ }$ & $\sqrt{ }$ & $\sqrt{ }$ & $\sqrt{ }$ & $\sqrt{ }$ & $\sqrt{ }$ & $\sqrt{ }$ & $\sqrt{ }$ \\
\hline Pedagang Grosir & $\sqrt{ }$ & $\sqrt{ }$ & $\sqrt{ }$ & $\sqrt{ }$ & $\sqrt{ }$ & $\sqrt{ }$ & $\sqrt{ }$ & $\sqrt{ }$ \\
\hline Pedagang Pengecer I & $\sqrt{ }$ & $\sqrt{ }$ & $\sqrt{ }$ & $\sqrt{ }$ & $\sqrt{ }$ & $\sqrt{ }$ & $\sqrt{ }$ & $\sqrt{ }$ \\
\hline \multicolumn{9}{|l|}{ Saluran II } \\
\hline Petani & $\sqrt{ }$ & - & - & $*$ & - & - & - & $\sqrt{ }$ \\
\hline Pedagang Pengumpul & $\sqrt{ }$ & $\sqrt{ }$ & $\sqrt{ }$ & $\sqrt{ }$ & $\sqrt{ }$ & $\sqrt{ }$ & $\sqrt{ }$ & $\sqrt{ }$ \\
\hline Pedagang Pengecer I & $\sqrt{ }$ & $\sqrt{ }$ & $\sqrt{ }$ & $\sqrt{ }$ & $\sqrt{ }$ & $\sqrt{ }$ & $\sqrt{ }$ & $\sqrt{ }$ \\
\hline \multicolumn{9}{|l|}{ Saluran III } \\
\hline Petani & $\sqrt{ }$ & - & - & $*$ & - & - & - & $\sqrt{ }$ \\
\hline Pedagang Pengumpul & $\sqrt{ }$ & $\sqrt{ }$ & $\sqrt{ }$ & $\sqrt{ }$ & $\sqrt{ }$ & $\sqrt{ }$ & $\sqrt{ }$ & $\sqrt{ }$ \\
\hline Pedagang Grosir & $\sqrt{ }$ & $\sqrt{ }$ & $\sqrt{ }$ & $\sqrt{ }$ & $\sqrt{ }$ & $\sqrt{ }$ & $\sqrt{ }$ & $\sqrt{ }$ \\
\hline Pedagang Pengecer I & $\sqrt{ }$ & $\sqrt{ }$ & $\sqrt{ }$ & $\sqrt{ }$ & $\sqrt{ }$ & $\sqrt{ }$ & $\sqrt{ }$ & $\sqrt{ }$ \\
\hline Pedagang Pengecer II & $\sqrt{ }$ & $\sqrt{ }$ & - & $\sqrt{ }$ & - & $\sqrt{ }$ & $\sqrt{ }$ & $\sqrt{ }$ \\
\hline
\end{tabular}

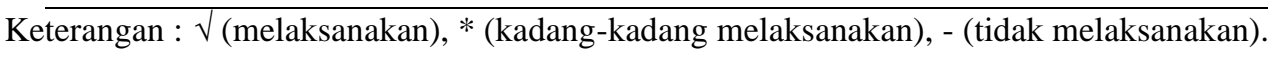

Berdasarkan Tabel 2 diatas fungsifungsi tataniaga pada setiap saluran pada umumnya melaksanakan fungsi pertukaran, fungsi fisik dan fungsi fasilitas. Fungsi pertukaran meliputi fungsi jual dan fungsi beli. Fungsi penjualan ini terjadi pada lembaga petani, pedagang pengumpul, pedagang grosir, pedagang pengecer I, pedagang pengecer II. Pada fungsi penjualan ini terjadi kegiatan perpindahan barang dari 
satu lembaga kelembaga lain seperti dari petani kepedagang pengumpul kemudian kepedagang grosir, kemudiam kepedagang pengecer I dan kepedagang pengecer II. Fungsi pembelian hanya terjadi pada pada lembaga pedagang pengumpul, pedagang grosir, pedagang penngecer I dan pedagang pengecer II. Pada fungsi pembelian terjadi perpindahan uang dari lembaga kelembaga lain, yang pada umumnya dari lembaga tingkat bawah kelembaga tingkat atas. Seperti dari lembaga pedagang grosir terjadi perpindahan uang kepedagang pengumpul dan seterusnya. Fungsi pembelian merupakan fungsi dimana terjadi transaksi perpindahan uang dari lembaga kelembaga yang lainnya. Fungsi penjualan dan pembelian merupakan fungsi dari pertukaran, dimana terjadi pertukaran antara barang dan uang, hal ini sesuai dengan pendapat Kohl dan Uhl (2002), yang menyatkan fungsi pertukaran merupakan kegiatan untuk memperlancar perpindahan hak milik dari barang atau jasa yang dipasarkan dari penjual kepada pembeli.

Fungsi fisik merupakan fungsi tataniaga yang berhubungan dengan kegiatan fisik seperti penyimpanan dan pengangkutan. Pada kegiatan penyimpanan, barang-barang disimpan dengan tujuan akan dijual kembali. Pada umumnya kegiatan penyimpanan pada cabai rawit tidak berlangsung lama, karena cabai rawit merupakan hasil tanaman hortikultura yang kurang tahan lama, hal ini sesuai dengan pendapat Rachmawati dkk (2009), berdasarkan hasil penelitannya bahwa pada hari ke-10 penyimpanan cabai rawit pada suhu kamar telah mengalami perubahan warna pada cabai rawit yaitu berubah warna coklat kehitaman.

Pada fungsi pengangkutan, terjadi hampir pada semua lembaga tataniaga cabai rawit di Kabupaten Kotawaringin Barat. Kegiatan pengangkutan pada petani kadangkadang dilakukan. Dari hasil penelitian produksi yang ada di petani ada yang langsung dijual ke pedagang pengumpul sehingga tidak memerlukan biaya pengangkutan, dan ada juga yang dijual langsung kepasar, sehingga ada biaya pengangkutan.
Fungsi fasilitas merupakan semua fasilitas yang mendukung agar tataniaga cabai rawit dapat berjalan dengan lancar. Dalam penelitian ini fungsi fasilitas meliputi sortasi, resiko, biaya dan informasi pasar. Proses sortasi merupakan suatu proses pemilihan cabai rawit, untuk memisahkan antara cabai rawit yang merah dan yang hijau atau antara cabai rawit yang masih berkualitas bagus dengan yang berkualitas rendah. Pengelompokkan cabai rawit ini dapat memberikan keuntungan bagi para pedagang, karena pedagang dapat menjual cabai rawit dengan berbagai variasi harga sesuai kualitas cabai rawit. Proses sortasi ini bertujuan untuk memperoleh harga terbaik untuk setiap kelasnya.

Resiko dalam tataniaga cabai rawit dialami oleh pedagang pengumpul, pedagang grosir dan pedagang pengecer. Resiko ini biasanya terjadi karena menurunnya kualitas dari caba rawit dan penyusutan berat cabai rawit yang disebabkan berkurangnya bobot karena banyaknya cabai yang rusak dan mulai mengalami kering. Resiko dalam tataniaga pada umumnya dialami oleh lembaga pemasaran.

Biaya pada umumnya ditanggung oleh lembaga pemasaran, seperti pedagang pengumpul, pedagang grosir dan pedagang pengecer. Biaya yang dikeluarkan oleh lembaga-lembaga tersebut meliputi pengangkutan, biaya sortasi ataupun biaya resiko selama tataniaga.

Informasi pasar dalam tataniaga hasil pertanian sangat diperlukan, baik dari tingkat petani sampai dengan tingkat pengecer. Fungsi dari informasi pasar salah satunya adalah untuk mengetahui permintaan dari cabai rawit dan harga dari cabai rawit itu sendiri. Dalam informasi pasar dapat diperoleh informasi, mengenai situasi dan kondisi perdagangan secara umum, harga jual yang diingankan konsumen dan situasi kondisi pasar secara keseluruhan. Hal ini sesuai dengan Sudiyono (2004), informasi pasar sangat diperlukan untuk mempertemukan potensial penawaran dan permintaan, serta informasi persediaan , kualitas komoditi ditingkat pasar pada tempat dan waktu tertentu. 


\section{Struktur Pasar}

Struktur pasar merupakan suatu kondisi dan perilaku pasar yang dihadapi oleh para pelaku pasar, baik oleh petani, pedagang pengumpul, pedagang grosir maupun pedagang eceren. Struktur pasar yang dihadapi oleh petani cabai rawit di Kabupaten Kotawaringin Barat adalah petani menghadapi satu pedagang pengumpul. Dalam penelitian ini ada 5 pedagang pengumpul, akan tetapi para pedagang pengumpul tersebut mempunyai daerah pembelian masing-masing karena berbeda kecamatan, sehingga petani hanya menghadapi satu pedagang pengumpul. Struktur pasar ditingkat petani mendekati pasar persaingan tidak sempurna. Hal ini sesuai dengan pendapat Azzaino (1982), yang menyatakan pasar monopsoni adalah merupakan salah satu jenis pasar dimana terdapat satu pembeli yang menguasai pasar.

Struktur pasar yang dihadapi oleh pedagang pengumpul yang berkaitan dengan petani adalah pasar persaingan tidak sempurna, karena hanya ada satu pembeli sedangkan penjualnya lebih banyak.
Struktur pasar pedagang pengumpul yang berkaitan dengan pedagang grosir dan pedagang eceran merupakan struktur pasar oligopoli, karena jumlah pedagang lebih sedikit dibandingkan dengan jumlah pembeli serta jenis barang dagangannya bersifat homogen.

Struktur pasar yang dihadapi oleh pedagang eceran yang berkaitan dengan konsumen adalah pasar persaingan sempurna, karena jumlah penjual dan pembeli sangat banyak, konsumen/pembeli mempunyai posisi tawar yang kuat, harga barang produk ditentukan oleh mekanisme pasar berupa permintaan dan penawaran.

\section{Margin dan Efesiensi Pemasaran Cabai Rawit}

Margin pemasaran merupakan perbedaan harga antara harga yang ada dikonsumen dengan harga yanga pada produsen dalam hal ini adalah petani. Berikut ini adalah tabel margin pemasaran cabai rawit di Kabupetan Kotawaringin Barat Tahun 2019.

Tabel 3. Biaya, Keuntungan, Marjin dan Efesiensi Pemasaran Cabai Rawit di Kabupaten Kotawaringin Barat Tahun 2019.

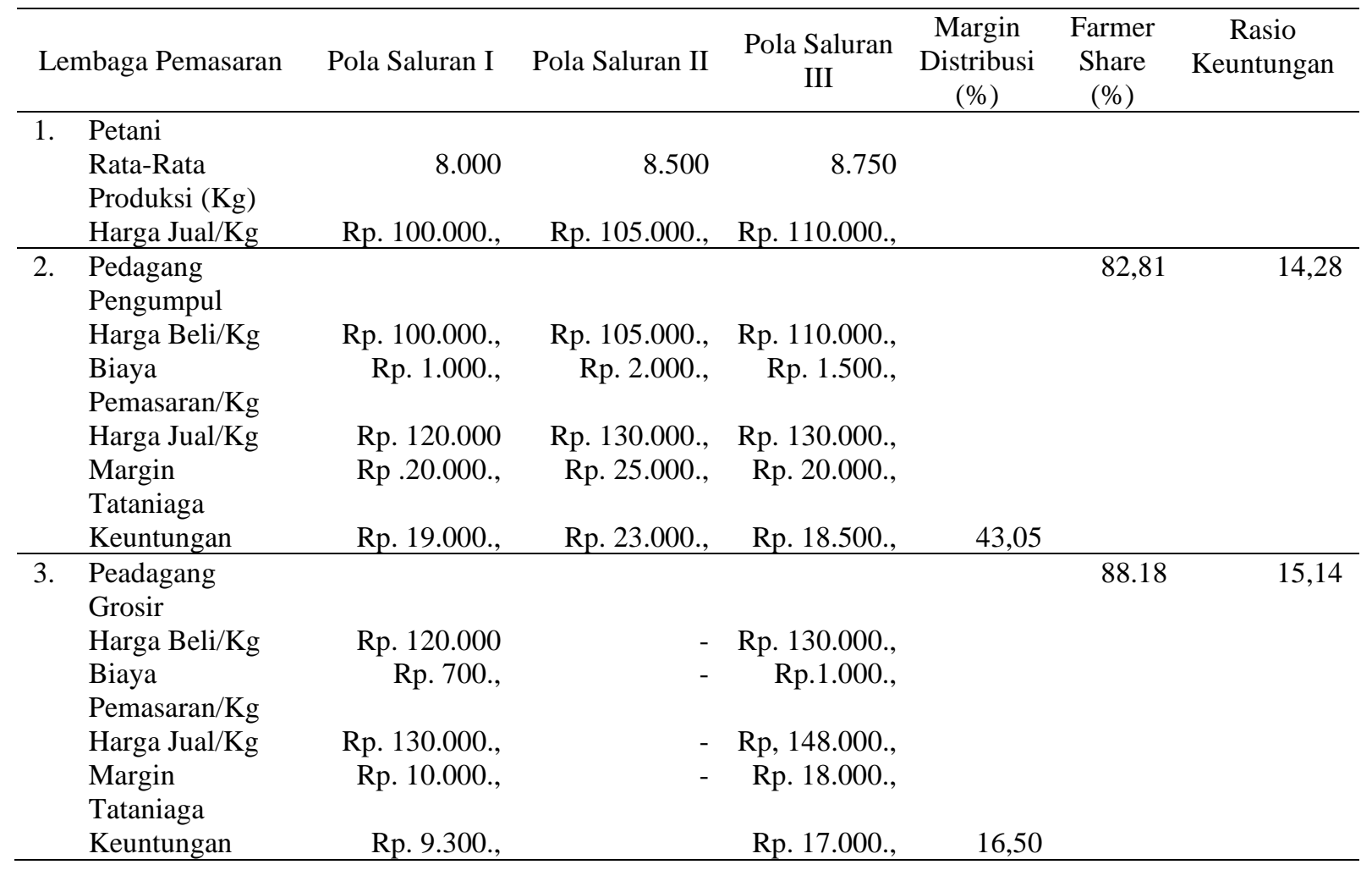




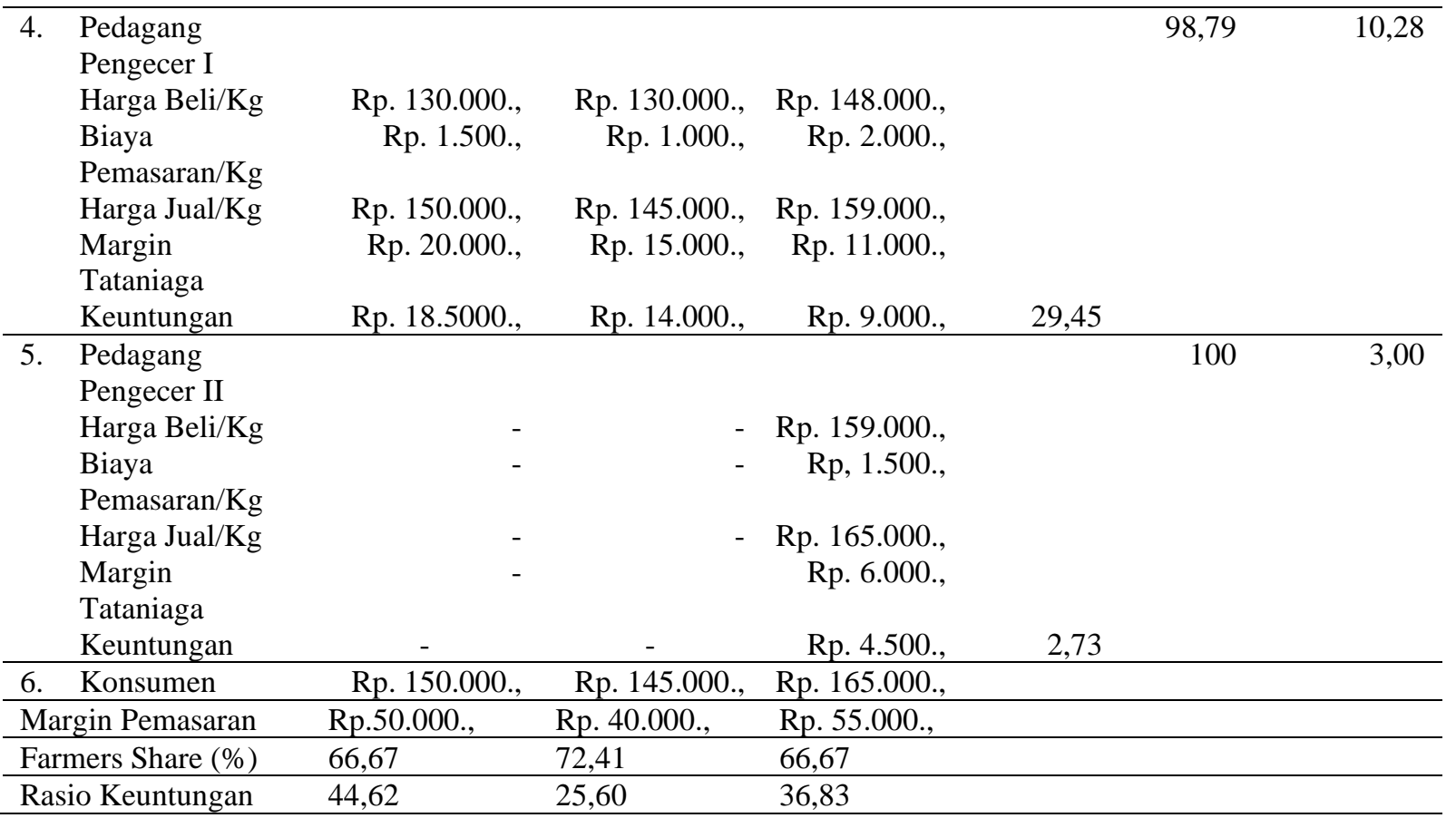

Berdasarkan data pada Tabel 3, dapat dilihat pada pola saluran I keuntungan terbesar terletak pada lembaga pemasaran pedagang pengumpul dengan jumlah keuntungan sebesar Rp. 19.000.,. Pada pola saluran II keuntungan terbesar terletak pada lembaga pemasaran pedagang pengumpul dengan jumlah keuntungan sebesar Rp. 23.000.,. Pada pola saluran III keuntungan terbesar terletak pada lembaga pemasaran pedagang pengumpul dengan jumlah keuntungan sebesar Rp. 18.500.,. Dari ke-3 (tiga) pola tersebut keuntungan terbesar terdapat pada lembaga pemasaran pedagang pengumpul. Pada pemasaran cabai rawit di Kabupaten Kotawaringin Barat petani menjual langsung kepedagang pengumpul, sehingga pedagang pengumpul adalah lembaga pertama yang mengetahui harga secara langsung dari petani. Pedagang pengumpul juga mengetahui harga secara langsung harga pasaran cabai rawit, sehingga pedagang pengumpul lebih mudah dalam mempermainkan harga. Pedagang pengumpul merupakan pedagang yang mengumpulkan hasil pertanian langsung dari petani, yang kemudian dijual kembali baik kepedagang grosir maupun kepedagang pengecer secara langsung.

Pada pola saluran I, margin pemasaran tertinggi terdapat pada lembaga pedagang pengumpul dan pedagang eceran I, yaitu sebesar Rp.20.000., Pada pola saluran II, margin pemasaran tertinggi terdapat pada lembaga pedagang pengumpul, yaitu sebesar Rp. 25.000.,. pada pola saluran III, margin pemasaran tertinggi terdapat pada lembaga pedagang pengumpul, yaitu sebesar Rp. 20.000., Dari ketiga pola saluran pemasaran cabai rawit di Kabupeten Kotawaringin Barat, margin pemasaran tertinggi terdapat pada lembaga pedagang pengumpul. Hal ini terjadi karena pedagang pengumpul mempunyai andil yang besar dalam proses tataniaga pemasaran cabai rawit. Andil pedagang pengumpul ini salah satunya adalah sebagai lembaga pertama yang langsung mengambil hasil pertanian secara langsung dari produsen dalam hal ini adalah petani.

Margin pemasaran adalah perbedaan harga pada tingkat yang berbeda dalam sistem pemasaran. Dari hasil peneitian margin pemasaran pada pola I adalah sebesar Rp. 50.000., pada pola II Rp. 40.000.- dan pada pola III adalah sebesar Rp. 55.000.-. dari ketiga pola saluran pemasaran cabai rawit yang ada di Kabupaten Kotawaringin Barat, margin terbesar terletak pada pola III yaitu sebesar Rp. 55.000.- pada pola saluran III, harga jual cabai rawit di petani adalah Rp. $110.000 .-/ \mathrm{kg}$ dan harga beli pada tingkat konsumen adalah Rp. 165.000.-/kg. Margin pemasaran pada pola saluran III paling tinggi, 
karena banyaknya lembaga-lembaga pemasaran yang dilalui. Lembaga-lembaga pemasaran pada pola saluran III ini dari petani ke pedagang pengumpul, pedagang grosir, pedagang eceran I, pedagang eceran II sampai akhirnya kekonsumen. Semakin panjang saluran pemasaran yang dilalui suatu produk maka harga yang diterima oleh konsumen semakin tinggi.

Efesiensi operasional pemasaran hasil pertanian dapat diukur dengan menggunakan analisis farmers share. Farmers share merupakan bagian harga yang diterima petani terhadap harga yang dibayarkan oleh konsumen. Berdasarkan hasil penelitian pemasaran cabai rawit di Kabupaten Kotawaringin Barat dari ke-3 (tiga) pola saluran pemasaran farmers share paling tinggi adalah terdapat pada pola saluran II, yaitu $72,41 \%$, sedangkan pada pola saluran I dan pola saluran III farmers share adalah 66,67\%.

Farmers share pada pola saluran II bernilai $72,41 \%$, ini berarti bahwa dari setiap Rp.100., yang dibayarkan oleh konsumen maka didistribusikan ke petani sebesar Rp. 72,41., semakin banyak bagian yang diterima oleh petani semakin memberikan keuntungan yang lebih untuk petani. Farmers share ini mempunyai nilai yang berbanding terbalik dengan margin pemasaran. Pada pola saluran II mempunyai nilai margin yang paling rendah (Rp. 40.000.,) dibandingkan pada pola saluran I dan III, yaitu Rp. 50.000.-.

Berdasarkan dari ke-3 pola saluran pemasaran cabai rawit, lembaga pemasaran yang mempunyai nila farmers share paling tinggi adalah lembaga pemasaran pedagang pengecer II, yaitu sebesar $100 \%$, yang berarti setiap Rp.100.-, yang bayarkan oleh konsumen maka didistribusikan ke pedagang pengecer I sebesar Rp. 100., sedangkan farmers share terendah terdapat pada lembaga pemasaran pedagang pengumpul yaitu 82,81 .

Rasio keuntungan merupakan perbandingan antara keuntungan yang diperoleh setiap lembaga dibagi dengan biaya yang dikeluarkan selama pemasaran cabai rawit. Berdasarkan hasil penelitian rasio keuntungan yang diperoleh dari ketiga pola saluran pemasaran, rata-rata rasio keuntungan cabai rawit di Kabupaten Kotawaringin Barat, terdapat pada lembaga pedagang grosir sebesar 15,14 , yang diikuti oleh pedagang pengumpul $(14,28)$, pedagang pedagang pengecer I $(10,28)$ dan pedagang pengecer II $(3,00)$.

Rasio keuntungan pada lembaga pedagang grosir dengan nilai sebesar 15,14 ini berarti bahwa setiap Rp. 1.-, biaya yang dikeluarkan dalam pemasaran cabai rawit di Kabupaten Kotawaringin Barat akan mendapatkan keuntungan sebesar Rp. 15,14.- Rasio keuntungan paling kecil adalah pada lembaga pengecer II, yaitu sebesar 3,00, yang berarti setiap Rp. 3.-, biaya yang dikeluarkan dalam pemasaran cabai tawit di Kabupaten Kotawaringin barat akan mendapatkan keuntungan sebesar Rp. 3.-.

Berdasarkan ke-3 (tiga) pola saluran pemasaran cabai rawit di Kabupaten Kotawaringin Barat, rasio keuntungan terbesar terdapat pada pola saluran I yaitu dengan nilai 44,62, yang berarti bahwa setiap Rp. 1.-, yang dikeluarkan untuk biaya pemasaran cabai rawit akan mendapatkan keuntungan sebesar Rp. 44,62.-. Rasio keuntungan paling kecil terdapat pada pola saluran II yaitu dengan nilai 25,60, yang berarti setiap Rp. 1.-, yang dikeluarkan untuk biaya pemasaran akan mendapatkan keuntungan sebesar Rp. 25,60.--

\section{KESIMPULAN}

Saluran tataniaga cabai rawit di Kabupaten Kotawaringin Barat ada tiga tingkatan saluran pemasaran, yaitu saluran dua tingkat, saluran tiga tingkat dan saluran empat tingkat. Lembaga pemasaran yang terlibat dalam tataniaga cabai rawit meliputi pedagang pengumpul, pedagang grosir, dan pedagang eceran. Pedagang pengumpul mempunyai fungsi mengumpulkan cabai rawit dari petani dan menjualnya kembali, pedagang grosir mempunyai fungsi membeli cabai rawit dari pedagang pengumpul dan menjualnya kembali, sedangkan pedagang eceran mempunyai fungsi membeli cabai rawit dari pedagang pengumpul maupun 
grosir dan menjual langsung kepada konsumen.

Margin tataniaga tertinggi terdapat pada saluran 3 (tiga) dan 4 (empat) tingkat yaitu dengan nilai Rp. 50.000.- dan margin tataniaga terendah terdapat pada saluran 2 (dua) tingkat yaitu dengan nilai Rp. 40.000.,. Nilai farmers share tertinggi terdapat pada saluran 2 (dua) tingkat dengan nilai 72,41 dan terendah terdapat pada saluran 3 (tiga) dan 4 (empat) tingkat dengan nilai 66,67.

Efesiensi tataniaga pemasaran cabai rawit di Kabupaten Kotawaringin Barat terdapat pada saluran pemasaran 2 (dua) tingkat, dimana cabai rawit untuk sampai kekonsumen akhir hanya melewati 2 (dua) lembaga pemasaran, dengan margin pemasaran antara petani dan konsumen bernilai Rp. 40.000., serta bagian yang yang diterima oleh petani sebesar Rp. 72,41., dari setiap Rp.100., yang dikeluarkan oleh konsumen.

\section{DAFTAR PUSTAKA}

Azzaino, Zulkifli. (1982). Pengantar Tataniaga Pertanian. Departemen Ilmu-Ilmu Sosial Ekonomi. Pertanian. Fakultas Pertanian. Institut Pertanian Bogor. Bogor.

Badan Pusat Statistik (BPS). 2018. Kotawaringin Barat Dalam Angka 2018. Badan Pusat Statistik Kabupaten Kotawaringin Barat.
Badan Pusat Statistik (BPS). (2019). Kotawaringin Barat Dalam Angka 2019. Badan Pusat Statistik. Kabupaten Kotawaringin Barat.

Kohl, R.L dan Uhl, J.N. (2002). Marketing of Agricultural Products. Ninth Edition. McMillan Publishing Company. New York.

Kotler, P. (2002). Manajemen Pemasaran. Edisi Millenium. Prehallindo. Jakarta.

Limbong, W.H. dan Sitorus, P. (1987). Pengantar Tataniaga Pertanian. Bahan Kuliah. Jurusan IlmuIlmu Sosial Ekonomi Pertanian. Fakultas Pertanian. Institut Pertanian Bogor. Bogor.

Rachmawati, R., Defiani, M.R. \& Suriani, N.L. (2009). Pengaruh suhu dan lama penyimpanan terhadap Kandungan vitamin C cabai rawit putih (Capsicum frustescens). Jurnal Biologi, 13(2), Retrieved from https://ojs.unud.ac.id/ index.php/BIO/article/view/584.

Sudiyono, A., (2004). Pemasaran Hasil Pertanian.

Muhammadiyah Universitas Malang. 